Mikko Keskinen \& Sanna Karkulebto

Kirjallisuus, Jyväskylän yliopisto

\title{
Jyväskylän yliopiston kirjallisuudentutkimus yhdistää monialaisesti esteettisen ja poliittisen
}

Jyväskylän yliopiston kirjallisuus-oppiaine on osa monialaista Taiteiden ja kulttuurin tutkimuksen laitosta. Laitoksen tutkimuksessa painottuvat tieteiden- ja taiteidenvälisyys sekä eri tieteiden, taiteiden ja medioiden rajapinnoilla tapahtuvat kulttuuriset ilmiöt, tilanteet ja toiminta.

Kirjallisuutta on opetettu Jyväskylän yliopistossa vuodesta 1958. Nelisen vuosikymmentä oppiaine oli jakautuneena kotimaiseen ja yleiseen linjaan, mutta nykyään linjaerottelua ei ole. Syventävien opintojen vaiheessa opiskelijat voivat valita myös kirjoittamisen suuntautumisvaihtoehdon, joka on ainoa laatuaan Suomessa. Monet alan opiskelijat hakeutuvatkin maisteri- ja tohtorivaiheessa Jyväskylään juuri kirjoittamisen ja siihen läheisesti liittyvän kokeellisuuden sekä tutkimuksen nykykirjallisuus- ja nykykulttuuripainotusten takia.

Myös opinnoissa korostuvat nykykirjallisuus ja -kulttuuri, unohtamatta kirjallisuuden historiaa, tyylikausia ja lajeja. Opintojen aikana perehdytään myös tekstien ja kirjallisuuden poliittisuuteen sekä kirjallisuuden ja yhteiskunnan välisiin yhteyksiin. Pyrkimyksenä on saavuttaa vahva tietämys kirjallisuuden perinteistä sekä kirjallisuustieteen teorioista ja menetelmistä. Opinnoissa otetaan huomioon myös kirjallisuuden lähialueet, kuten visuaalinen, auditiivinen ja audiovisuaalinen kulttuuri. Kirjoittamisen suuntautumisvaihtoehdon opinnoissa kohtaavat luova kirjoittaminen, kirjoittamisen pedagogia ja tutkimus.

Oppiaineessa työskentelee kaksi ja puoli professoria (Mikko Keskinen, Sanna Karkulehto ja kirjoittamisen ja hungarologian välillä työpanoksensa jakava Tuomo Lahdelma), yliopistonlehtori, yliopistotutkija ja yliopistonopettaja. Keskisen tutkimusintresseihin kuuluvat angloamerikkalainen nykyproosa, kertomuksen teoria, intermediaalisuus, ääni ja puhe kirjallisuudessa, toisto ja kirjallinen ero sekä kokeellinen kerronta. Karkulehdon tutkimusalueita ovat kotimainen nykykirjallisuus, tekstien valta ja erojen politiikka, sukupuoli, seksuaalisuus ja ruumiillisuus sekä mediakulttuuri ja kulttuuriteoria. Lahdelma tutkii Unkarin kirjallisuutta, terapiakirjoittamista, kirjallisuuden kääntämistä ja tekijyyttä. Yliopistonlehtori Risto Niemi-Pynttäri keskittyy tutkimuksessaan verkkoproosaan sekä kirjoittamisen prosesseihin ja filosofiaan; hän myös toimittaa kirjoittamisen tutkimuksen Scriptum-lehteä. Yliopistotutkija Mika Hallilan (joka toi- 
mii vierailevana professorina Varsovan yliopistossa ja jota sijaistaa Anna Helle) erikoisalaa ovat romaanin teoria, metafiktio ja suomalainen nykyromaani. Yliopistonopettaja Kaisa Ahvenjärven (jonka sijaisena toimii Ate Tervonen) tutkimusalat ovat kirjallisuuspedagogiikka ja saamelaiskirjallisuus.

Oppiaine on partnerina Suomen Akatemian konsortiohankkeessa The Literary in Life: Exploring the Boundaries between Literature and the Everyday (2015-2019), jossa Keskisen johtama Jyväskylän ryhmä (Anna Helle, Juri Joensuu ja Laura Piippo) tutkii Suomen 2000-luvun kokeellisen kirjallisuuden poetiikkaa ja politiikkaa kytkemällä muodolliset ja menetelmälliset operaatiot sosiaalis-affektiivisiin merkityksiin ja vaikutuksiin.

Karkulehdon johtaman monitieteisen tutkimusryhmän (Satu Koho, Aino-Kaisa Koistinen, Leena-Maija Rossi, Myry Voipio) hanke Abusive Sexuality and Sexual Violence in Contemporary Culture (Koneen Säätiö) päättyy tänä vuonna. Projektin aikana kasvaneen ryhmän (Kaisa Ahvenjärvi, Tuija Saresma) jatkotavoitteena on tarkastella Pohjoismaissa nopeasti levinneiden vihan, aggression ja väkivallan diskurssien dominoimaa kulttuuria kriittisesti toisin. Jyväskylässä on meneillään myös Anna Pehkorannan post doc -hanke Minority Avant-Gardes: Literary Form and Affective Investment in Contemporary Experimental and Transgressive Asian American Literature (Koneen Säätiö, 2016-2018).

2000-luvulla oppiaineessa on toteutettu Suomen Akatemian hankkeita (mm. Keskisen projektit Ä̈̈nikirja, Kirjaimellisia versioita ja Verkostoitunut kirjallisuus sekä Karkulehdon Seksuaalisuuden, väkivallan ja talouden representaatiot sekä intersektionaalisuus kotimaisessa nykykirjallisuudessa). Oppiaineen henkilökunta oli vahvasti mukana myös Suomen nykykirjallisuus I-II -kirjahankkeen (SKS 2013) toimittajina ja kirjoittajina.

Oppiaineen hiljattaiset väitöstutkimukset kytkeytyvät muun muassa postkoloniaalisuuteen ja transnationaalisuuteen. Monia meneillään olevia hankkeita yhdistää kiinnostus affekteihin, uusmateriaalisuuteen ja posthumanistiseen teoriaan sekä niiden yhdistelmiin. Teatteria, elokuvaa ja sarjakuvaa tarkastellaan yhtäältä kokeellisuuden, (inter)mediaalisuuden ja narratologian, toisaalta sukupuoli- ja seksuaalisuusteorioiden näkökulmista. Lajien ja tekijyyden suhdetta valtaan tutkitaan kirjallisuushistoriallisessa ja -institutionaalisessa kehyksessä.

Jyväskylälle on tunnusomaista vireä kirjallinen elämä myös yliopiston ulkopuolella; monet maan johtavista kirjailijoista ja kustannustoimittajista ovat oppiaineen alumneja.

https://www.jyu.fi/hum/laitokset/taiku/opiskelu/kirjallisuus 